\title{
Protist control of phytoplankton growth in the subtropical north-east Atlantic
}

\author{
Mario Quevedo*, Ricardo Anadón \\ Departamento de Biología de Organismos y Sistemas, Area de Ecología, Universidad de Oviedo, \\ Catedrático Rodrigo Uría s/n, 33071 Oviedo Asturias, Spain
}

\begin{abstract}
The grazing impact of protists on phytoplankton primary production in a highly oligotrophic area of the subtropical north-east Atlantic, south-east of the Azores, was studied using the dilution method. The phytoplankton community in the experiments, analysed by flow-cytometry, was dominated by Prochlorococcus and Synechococcus although larger phototrophic groups, beyond flow-cytometry sensitivity, were also present. The microzooplankton community was dominated by small gymnodinoid dinoflagellates and aloricate ciliates, and its biomass was low, averaging $0.7 \mathrm{mg}$ $\mathrm{C} \mathrm{m}^{-3}$. We measured average phytoplankton growth rates of 0.76 and $0.22 \mathrm{~d}^{-1}$ in surface waters and in deep chlorophyll maximum (DCM) waters respectively; mortality rates due to protists grazing were 0.58 and $0.22 \mathrm{~d}^{-1}$, respectively. We did not find significant differences in growth and mortality rates of the different phytoplankton groups, i.e. Prochlorococcus, Synechococcus or nanoeukaryotes; thus no prey preference was apparent from the results. Protists consumed on average 79 and $109 \%$ of primary production in surface and DCM waters respectively, controlling phytoplankton growth in the area. The net primary production closely oscillated around zero in the chlorophyll a analyses and was positive in the flow-cytometry analyses, suggesting a balanced or slightly autotrophic phytoplanktonprotist compartment.
\end{abstract}

KEY WORDS: Protists grazing $\cdot$ Trophic coupling $\cdot$ DCM $\cdot$ Subtropical NE Atlantic $\cdot$ Phytoplankton groups Resale or republication not permitted without written consent of the publisher

\section{INTRODUCTION}

The oligotrophic regions of the ocean, which occupy large areas and account for ca $25 \%$ of global phytoplankton primary production (Behrenfeld \& Falkowski 1997), are the subject of debate as to the autotrophic-heterotrophic nature of their carbon balance (Williams 1998). This greatly depends on e.g. the availability of nutrients, the efficiency of heterotrophic bacteria, the existence of allochthonous inputs of carbon, and the role of heterotrophic protists in controlling phytoplankton populations, i.e. by consuming organic carbon arising from primary production. The latter factor is not often addressed ex-

*E-mail: mquevedo@sci.cpd.uniovi.es perimentally in open-ocean carbon budgets (Fasham et al. 1999).

The low phytoplankton standing stocks of oligotrophic ocean ecosystems (Cebrián \& Duarte 1994), the size structure of their dominant phytoplankton communities (Hansen et al. 1994), and the growth rates of ultraphytoplankton and protist grazers (Fogg 1995) make conceivable the existence of tight coupling between producers and protist grazers in these regions. Such efficient coupling would result in a great fraction of their primary production being channeled to sustain local heterotrophic metabolism, efficient nutrient recycling, and a close balance between photosynthetic production and community respiration (Duarte \& Cebrián 1996). Despite such evidence of the capability of microzooplankton to influence the dynamics of highly oligotrophic waters, present knowledge of 
microzooplankton grazing activity or biomass in these areas is scarce.

The most oligotrophic areas of the Atlantic Ocean do not differ from other oligotrophic zones in their low temporal variability in photosynthetic plankton, which is largely dominated by picoplankton and small nanoflagellates, accounting for 70 to $90 \%$ of the total photosynthetic biomass (Marañón et al. 2000). In particular, the subtropical north-east Atlantic has been described as being more heterotrophic than the neighbouring tropical and North Atlantic Drift regions, with biomass attributable to heterotrophs exceeding $50 \%$ from $26^{\circ}$ to $45^{\circ} \mathrm{N}$ (Buck et al. 1996). The comparatively shallower nitracline and distinctly higher chl a levels (Pingree et al. 1999, Marañón et al. 2000) of the adjacent biogeochemical provinces north of the Subtropical Front and south of the $20^{\circ} \mathrm{N}$ parallel (Longhurst 1998) indicate more productive systems in which the portion of new production should be higher.

To determine the herbivorous impact of broadly defined microzooplankton, and the extent of its coupling with phytoplankton production, we carried out experiments using the dilution method (Landry \& Hassett 1982). This method determines simultaneously the rates of phytoplankton growth and mortality due to the grazing activity of protists. In addition, it allows estimation of phytoplankton primary production without the use of ${ }^{14} \mathrm{C}$, which method has been reported to underestimate primary production compared to the dilution method (Moigis 1999).

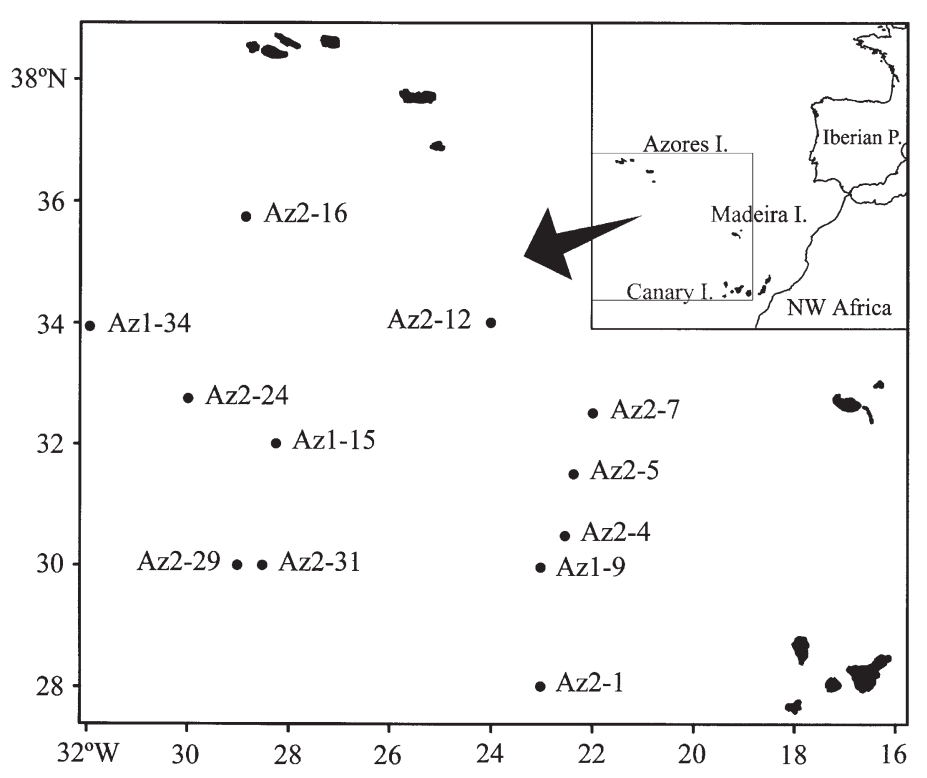

Fig. 1. Study area and locations of sampling stations on Cruises Az1 and Az2 of the RV 'Hespérides'

\section{METHODS}

The study was conducted on board the RV 'Hespérides' during the CANIGO Project Cruises Azores1 and Azores2 (hereafter Az1 and Az2), in August 1998 and April 1999, respectively. The area studied was the North Atlantic subtropical region south-east of the Azores Islands (Fig. 1).

Grazing experiments. We used the dilution method (Landry \& Hassett 1982) to estimate instantaneous rates of growth $(\mu)$ and grazing mortality $(m)$ of phytoplankton. The method is based on the measurement of algal net growth rate $(r)$ along a gradient of dilution levels, which should uncouple phytoplankton growth and protist grazing, assuming exponential algal growth:

$$
r=t^{-1} \ln \left(P_{\mathrm{t}} P_{0}^{-1}\right)
$$

where $P_{\mathrm{t}}$ is the concentration of phytoplankton at $t_{24}$ and $P_{0}$ is the initial concentration. Linear regression analysis of the dilution factor (DL) against $r$ yields slope and intercept values corresponding to instantaneous microzooplankton grazing $(m)$ and phytoplankton growth rate $(\mu)$ :

$$
r=\mu-(m \mathrm{DL})
$$

Provided that the experiments are conducted with nutrient enrichment, the intercept of the linear regression yields the instantaneous growth rate in the absence of grazers and with added nutrients $\left(\mu_{\mathrm{n}}\right)$. The mortality rate $(m)$ was subsequently added to the net growth rate in the unenriched natural seawater treatment $\left(r_{100 \%}\right)$ to obtain an estimate of phytoplankton growth rate without added nutrients $\left(\mu_{0}=r_{100 \%}+m\right)$. Phytoplankton biomass production (PP) and grazing losses $(G)$ can be calculated from the following equations (Landry et al. 2000): $\mathrm{PP}=\mu_{0} \times P_{\mathrm{m}}, G=m \times P_{\mathrm{m}}$, and

$$
P_{\mathrm{m}}=P_{0} \times\left(\mathrm{e}^{(\mu-m) t}-1\right) /\left(\mu_{0}-m\right) t
$$

where $P_{\mathrm{m}}$ is the geometric mean concentration of phytoplankton during the experiment.

The assessment of the grazing rates of pelagic protists does not have a definitive methodological solution (Landry 1994). We chose to use the dilution method because it provides estimates of growth and grazing mortality at the community level, without addition of chemicals or great cell damage. Secondly, the method was also the most convenient because the manipulation is reasonably simple, an advantage with a multidisciplinary survey and limited work force. However, the method relies on some assumptions and essential factors that should be considered, such as the possible differential nutrient availability arising because nutrients would be depleted more rapidly in dilution treatments with higher plankton densities. This is the case in oligo- 
trophic systems such as that considered here, but it can be overcome by adding nutrients to incubation bottles while keeping controls without nutrient addition (Landry 1994). Another essential assumption of the dilution method is that the clearance rate of microzooplankton remains constant at all dilution levels. This assumption would be compromised by any non-linear functional response of grazers during the dilution series. In the highly oligotrophic environment studied here, any non-linearity is presumed to derive from feeding thresholds at higher dilution levels (Gallegos 1989). Related to this is the possible effect of dilution series on the growth rates of grazers. Finally, on-deck incubations at simulated in situ irradiance could induce artefacts due to photoadaptation, i.e. pigment content per cell changing as a consequence of incubating at an irradiance level different from the ambient one.

Experimental set-up. Water for the experiments was collected at the near-surface (5 to $7 \mathrm{~m}$ ) and at the deep chlorophyll maximum (DCM) levels. Surface experiments were intended to represent the shallow upper mixed layer, while the DCM was targeted because it is a consistent, conspicuous feature of subtropical and tropical waters (Fasham et al. 1985). Although the DCM is not necessarily a biomass maximum (Cullen 1982, Marañón et al. 2000), processes at this depth are expected to differ from those in the upper mixed layer on the basis of different light and nutrient availability.

Experimental water was collected always during dark hours (04:30 to 06:00 h local time) using 30 or $5 \mathrm{l}$ Niskin bottles. Between experiments, carboys, bottles, capsule filters and tubing were stored in $10 \% \mathrm{HCl}$ Milli-Q water, and rinsed sequentially with Milli-Q and $0.2 \mu \mathrm{m}$ filtered seawater immediately before use. From the DCM or surface, 251 were gently transferred to a polycarbonate carboy fully wrapped in black plastic, using silicone tubing fitted with $200 \mu \mathrm{m}$ mesh to eliminate mesozooplankton. Simultaneously, another 251 from the same depth were filtered through a Gelman Suporcap 100 capsule filter $(0.2 \mu \mathrm{m})$ to obtain the dilution water. Water filtered through the capsules showed undetectable chl a values and negligible numbers of fluorescent particles when examined by flow cytometry. New capsules were soaked a few hours in $10 \%$ $\mathrm{HCl}$ and rinsed with Milli-Q water before first use. In addition, the first $10 \mathrm{l}$ of seawater filtered with the capsules were discarded in every experiment. Capsules were changed every 4 experiments. Unfiltered, prescreened seawater was mixed with filtered seawater in 2.31 polycarbonate bottles to obtain replicate dilutions of $100,80,60,40$ and $20 \%$. An extra bottle for each dilution level was prepared and used as the initial chl a sample. To avoid nutrient limitation of phytoplankton growth, a mixture of $1 \mu \mathrm{M}$ ammonium $\left(\mathrm{NH}_{4} \mathrm{Cl}\right), 0.5 \mu \mathrm{M}$ phosphate $\left(\mathrm{H}_{3} \mathrm{PO}_{4}\right), 5 \mathrm{nM}$ iron $\left(\mathrm{FeSO}_{4}\right)$ and $0.1 \mathrm{nM}$ manganese $\left(\mathrm{MnSO}_{4}\right)$ was added to each bottle. Two supplementary bottles of $100 \%$ natural seawater were incubated as controls without added nutrients. Bottles were kept in the dark during the whole process until introduced into the incubator. Powder-free plastic gloves were used throughout manipulation. Incubations were run in on-deck incubators, starting always within $1.5 \mathrm{~h}$ of water collection and lasting $24 \mathrm{~h}$. Sheets of light filters were combined to simulate in-situ irradiance (see Table 1). When necessary, the combination of light filters (prepared during hours of darkness) was corrected after light measurements in the morning, thus correcting possible small shifts in the amount of irradiance reaching the DCM. The temperature for the DCM incubations was controlled by means of 2 thermostats connected to a cooler and to a heater respectively, which maintained the water within $\pm 0.5^{\circ} \mathrm{C}$ of the in situ temperature. Water inside the incubator was homogenised with 2 submersible pumps. The temperature in the surface incubations was controlled with water running from the underway $(7 \mathrm{~m})$ pump.

Sampling procedure and analysis. Samples for fluorometric chl a analysis were collected from each bottle (500 to $1000 \mathrm{ml}$ depending on the dilution level) and filtered in dark filter funnels onto Whatmann $25 \mathrm{~mm}$ GF/F filters. The filters were frozen and stored in the dark. Chl a was measured in a fluorometer (Turner Designs, Sunnyvale, CA) after $16 \mathrm{~h}$ extraction of pigments in $90 \%$ cold acetone. To determine the abundance and biomass of microzooplankton, $500 \mathrm{ml} \mathrm{sam-}$ ples of the $100 \%$ dilution treatment were collected at $t_{0}$ for each experiment and at $t_{24}$ for several experiments. Samples were fixed in pre-added acid Lugol solution ( $5 \%$ final conc.), and stored at $5^{\circ} \mathrm{C}$ in the dark. Preceding analysis, the whole samples were settled in $500 \mathrm{ml}$ test tubes for at least $6 \mathrm{~d}$. The upper $450 \mathrm{ml}$ were gently siphoned and discarded, and the rest of the samples were allowed to settle for a minimum of $20 \mathrm{~h}$ in $25 \mathrm{~mm}$ $\varnothing$ Utermöhl chambers. The samples were then analysed under a phase-contrast Olympus IMT-2 inverted microscope, at magnifications of $150 \times, 400 \times$ or $600 \times$. To account for the possibility of cell losses during the sedimentation process, a correction factor (i.e. 1.3 for small dinoflagellates and ca 1.0 for small ciliates and larger protists) was obtained from the average number of cells remaining in the discarded portions of $5 \mathrm{sam}$ ples. To estimate microzooplankton biomass, linear dimensions of dinoflagellates and ciliates were measured with an image-analysis system attached to the inverted microscope and converted to volumes assuming simple geometric shapes. Carbon content was estimated from volume using $0.19 \mathrm{pg} \mathrm{C} \mathrm{\mu m}^{-3}$ for Lugolpreserved ciliates (Putt \& Stoecker 1989) and 0.14 pg $\mathrm{C} \mathrm{m}^{-3}$ for dinoflagellates (Lessard 1991). Although many photosynthetic dinoflagellates are known to 
feature both phagotrophy and extracellular digestion (Gaines \& Elbrächter 1987), only phagotroph or mixotroph genera according to Lessard \& Swift (1986) and Gaines \& Elbrächter (1987) were considered.

To gain knowledge about the trophic status of dinoflagellates and to estimate the abundance of heterotrophic nanoflagellates (HNF) in the area, $100 \mathrm{ml}$ samples for epifluorescence microscopy were collected during the Az1 cruise. They were fixed in glutaraldehyde ( $0.5 \%$ final conc.), stained with DAPI $\left(25 \mu \mathrm{g} \mathrm{ml} \mathrm{m}^{-1}\right.$ final conc.) for 5 to $7 \mathrm{~min}$ in the dark, and filtered onto a black $0.8 \mu \mathrm{m}$ polycarbonate filter at low vacuum (<25 mm Hg). A $1.0 \mu \mathrm{m}$ pore-size cellulose filter was used as a backing filter to facilitate an even distribution of cells. Filters were mounted onto microscope slides, covered with a drop of Cargille DF low-fluorescence immersion oil and the cover glass. They were then stored for $24 \mathrm{~h}$ at $4^{\circ} \mathrm{C}$ to allow replacement of the water by immersion oil, and frozen at $-20^{\circ} \mathrm{C}$. Samples were analysed at $400 \times$ and $1000 \times$ magnification with a Leitz microscope (100 W mercury lamp) under UV (334 to $365 \mathrm{~nm}$ ) and blue (435 to $490 \mathrm{~nm}$ ) light for detection of nuclei and to check for chlorophyll autofluorescence. To enumerate HNF, a transect of the filter was examined at $400 \times(435 \mu \mathrm{m} \times 24000 \mu \mathrm{m})$.

During Cruise Az2, we collected samples for flowcytometry (FCM) analysis from 7 dilution experiments. Samples at $t_{0}$ were collected from the $100 \%$ level, while $t_{24}$ samples were collected from 1 replicate of each dilution treatment. Samples were fixed in glutaraldehyde (pre-filtered through $0.2 \mu \mathrm{m}$ polycarbonate filter, $1 \%$ final conc.) and stored in liquid nitrogen until analysis on a FacScan flow cytometer (Becton Dickinson, Franklin Lakes, NJ). Phytoplankton groups were characterised and enumerated according to their side-light scatter, orange $(585 \pm 21 \mathrm{~nm})$ and red
(>650 nm) fluorescence signals. Samples were run at $88 \mu \mathrm{l} \mathrm{min}{ }^{-1}$ for $1 \mathrm{~min}$ for picoplankton and $3 \mathrm{~min}$ for nanoeukaryotes. Three major groups were identified: Prochlorococcus, Synechococcus and nanoeukaryotes. The relative contribution of each group in terms of carbon and chlorophyll was estimated assuming that cell carbon and chlorophyll are proportional to mean cell side scatter and red fluorescence, respectively ( $\mathrm{Li}$ 1995).

Statistical analysis. Differences in mortality rates between FCM groups were analysed by slope homogeneity in regression lines between net growth rate and dilution factor. The null hypothesis $\left(H_{0}\right)$ tested, was that the slope of Prochlorococcus, Synechococcus and nanoeukaryotes was equal within each experiment. For experiments with homogeneous slopes a common mortality rate $m_{c}$ was calculated; a Tukey test was used for heterogeneous slopes (Zar 1999). Statistica (Statsoft, Tulsa, OK) and SPSS (SPSS, Chicago, IL) statistical packages were used for these analyses.

\section{RESULTS}

During Cruise Az1, a shallow thermocline and high surface temperature prevailed (Pérez et al. unpubl. data), while the euphotic layer during Cruise Az2 was less stratified and ambient temperature was lower (González et al. 2001). Chl a concentration was always below $0.1 \mathrm{mg} \mathrm{m}^{-3}$ in the surface water, while initial chl $a$ in experiments conducted with DCM water ranged from 0.07 to $0.39 \mathrm{mg} \mathrm{m}^{-3}\left(P_{0}\right.$ : Table 1$)$. Ambient nitrate concentration in the experiments was below $0.3 \mu \mathrm{M}$ except for Stns Az1-15 and Az2-16, where it was 1.9 and $0.8 \mu \mathrm{M}$, respectively.

Table 1. Initial experimental conditions. $P_{0}$ : initial chlorophyll concentration; $\% I_{0:}$ percentage of incident surface irradiance used in the incubation. PRO, SYN, Neuk: abundance of Prochlorococcus, Synechococcus and autotrophic nanoeukaryotes where flow-cytometry samples were available (Cruise Az2); $D_{0}$ : microzooplankton abundance; $B_{0}$ : microzooplankton biomass

\begin{tabular}{|c|c|c|c|c|c|c|c|c|c|c|}
\hline Date & Stn & $\begin{array}{l}\text { Depth } \\
\text { (m) }\end{array}$ & $\begin{array}{c}T \\
\left({ }^{\circ} \mathrm{C}\right)\end{array}$ & $\begin{array}{c}P_{0} \\
\left(\mathrm{mg} \mathrm{chl} a \mathrm{~m}^{-3}\right)\end{array}$ & $\% I_{0}$ & $\begin{array}{c}\text { PRO } \\
\left(10^{3} \text { cells ml }{ }^{-1}\right)\end{array}$ & $\begin{array}{c}\text { SYN } \\
\left(10^{3} \text { cells ml }{ }^{-1}\right)\end{array}$ & $\begin{array}{c}\text { Neuk } \\
\left(10^{3} \text { cells } \mathrm{ml}^{-1}\right)\end{array}$ & $\begin{array}{c}D_{0} \\
\left(10^{3} \text { cell }^{-1}\right)\end{array}$ & $\begin{array}{c}B_{0} \\
\left(\mathrm{mg} \mathrm{C} \mathrm{m}^{-3}\right)\end{array}$ \\
\hline 06 Aug 98 & Az1-9 & 5 & 23.2 & 0.05 & 55 & - & - & - & 0.6 & 0.3 \\
\hline 16 Aug 98 & Az1-34 & 5 & 26.2 & 0.07 & 55 & - & - & - & 1.1 & 0.7 \\
\hline 10 Apr 99 & Az2-4 & 5 & 19.4 & 0.05 & 55 & 33 & 33 & 1.6 & 1.4 & 0.5 \\
\hline 25 Apr 99 & Az2-29 & 10 & 20.9 & 0.03 & 55 & 14 & 5.8 & 1.0 & 1.4 & 0.9 \\
\hline 09 Aug 98 & Az1-15 & 94 & 19.4 & 0.25 & 2 & - & - & - & 1.9 & 0.7 \\
\hline 08 Apr 99 & Az2-1 & 84 & 19.4 & 0.16 & 2 & - & - & - & 1.4 & 0.5 \\
\hline 11 Apr 99 & Az2-5 & 75 & 18.6 & 0.39 & 2 & - & - & - & 1.6 & 0.5 \\
\hline 12 Apr 99 & Az2-7 & 72 & 18.1 & 0.33 & 4.5 & 37 & 18 & 5.3 & 1.8 & 1.3 \\
\hline 16 Apr 99 & Az2-12 & 75 & 18.1 & 0.14 & 4.5 & 81 & 9.4 & 3.7 & 2.4 & 0.7 \\
\hline 18 Apr 99 & Az2-16 & 80 & 17.4 & 0.07 & 4.5 & 56 & 10 & 7.1 & 2.0 & 0.8 \\
\hline 24 Apr 99 & Az2-24 & 98 & 18.3 & 0.29 & 4.5 & 57 & 4.6 & 3.2 & - & - \\
\hline 26 Apr 99 & Az2-31 & 70 & 19.1 & 0.39 & 4.5 & 115 & 11 & 6.8 & 0.8 & 0.2 \\
\hline
\end{tabular}




\section{Phytoplankton abundance}

During Cruise Az2, the abundance of phytoplankton groups that could be determined by FCM ranged from 21 to $133 \times 10^{3}$ cells $\mathrm{ml}^{-1}$ in $t_{0}$ samples. The photosynthetic prokaryote Prochlorococcus dominated numerically in most experiments, except for the surface at Stn Az2-4, where it was matched by Synechococcus (Table 1). Mean percentage numerical composition was $73 \%$ Prochlorococcus, $21 \%$ Synechococcus and $6 \%$ larger, bright fluorescing nanoeukaryotes. For carbon biomass and chl $a$, the percentage compositions were 68, 22, 10 and 64, 27, 9 for Prochlorococcus, Synechococcus and nanoeukaryotes, respectively. However, processing epifluorescence samples to enumerate $\mathrm{HNF}$ revealed evidence of the substantial presence of larger cells beyond the detection limits of FCM, i.e. phototrophic nanoflagellates of ca 10 to $15 \mu \mathrm{m}$.

\section{Microzooplankton abundance and biomass}

Microzooplankton abundance and biomass were low, ranging from 0.6 to $2.4 \times 10^{3}$ cells $\mathrm{l}^{-1}$ and 0.2 to $1.3 \mathrm{mg} \mathrm{C} \mathrm{m}^{-1}$, respectively (Table 1 ). The community was dominated by cells smaller than $20 \mu \mathrm{m}$ which represented $72 \%$ of the total abundance and $23 \%$ of the total biomass. These nano-sized cells were composed of gymnodinoid dinoflagellates and small aloricate ciliates, the former accounting for $54 \%$ of the total abundance and $14 \%$ of the total biomass, and the latter accounting for $19 \%$ of the abundance and $9 \%$ of the biomass. Larger heterotrophic dinoflagellates represented by Gymnodinium, Gyrodinium, Cochlodinium and Torodinium species, and aloricate ciliates $>20 \mu \mathrm{m}$ composed of Strombidium, Strobilidium and Tontonia species, accounted for 11 and $17 \%$ of the total abundance respectively, and dominated the biomass, accounting for 20 and $57 \%$ respectively. In addition to the abundance and biomass of microzooplankton, the abundance of HNF ranged from 20 to 87 cells $\mathrm{ml}^{-1}$, with an average number of 41 cells $\mathrm{ml}^{-1}$, on a roughly latitudinal transect ( 37.59 to $29.58^{\circ} \mathrm{N}, 20.35$ to $23.00^{\circ} \mathrm{W}$ ) during Cruise Az1. Examination of the trophic condition of dinoflagellates during Cruise Az1 showed that $57 \%$ of the small gymnodinoids and $63 \%$ of the small thecate cells lacked chloroplasts.

\section{Shifts in cell pigments}

The mean red and orange fluorescence signals per cell used to control for possible artefacts due to photoadaptation showed that final signals were not significantly different from initial signals (2-tailed paired- sample $t$-tests). The average ratios between final and initial red fluorescence signals were $1.11 \pm 0.16,0.94 \pm$ 0.12 and $0.98 \pm 0.09$ (mean \pm SD) for Synechococcus, Prochlorococcus and nanoeukaryotes, respectively. The average ratio in the mean orange fluorescence signal was $1.12 \pm 0.19$ for Synechococcus.

\section{Growth and mortality}

The response of phytoplankton net growth rate to the dilution treatments appeared fairly linear with both the chl $a$ and FCM approaches. An exception was experiment Az1-34, in which phytoplankton growth rate peaked at the highest dilution level (Fig. 2). Tests of the linear-response assumption in the equatorial

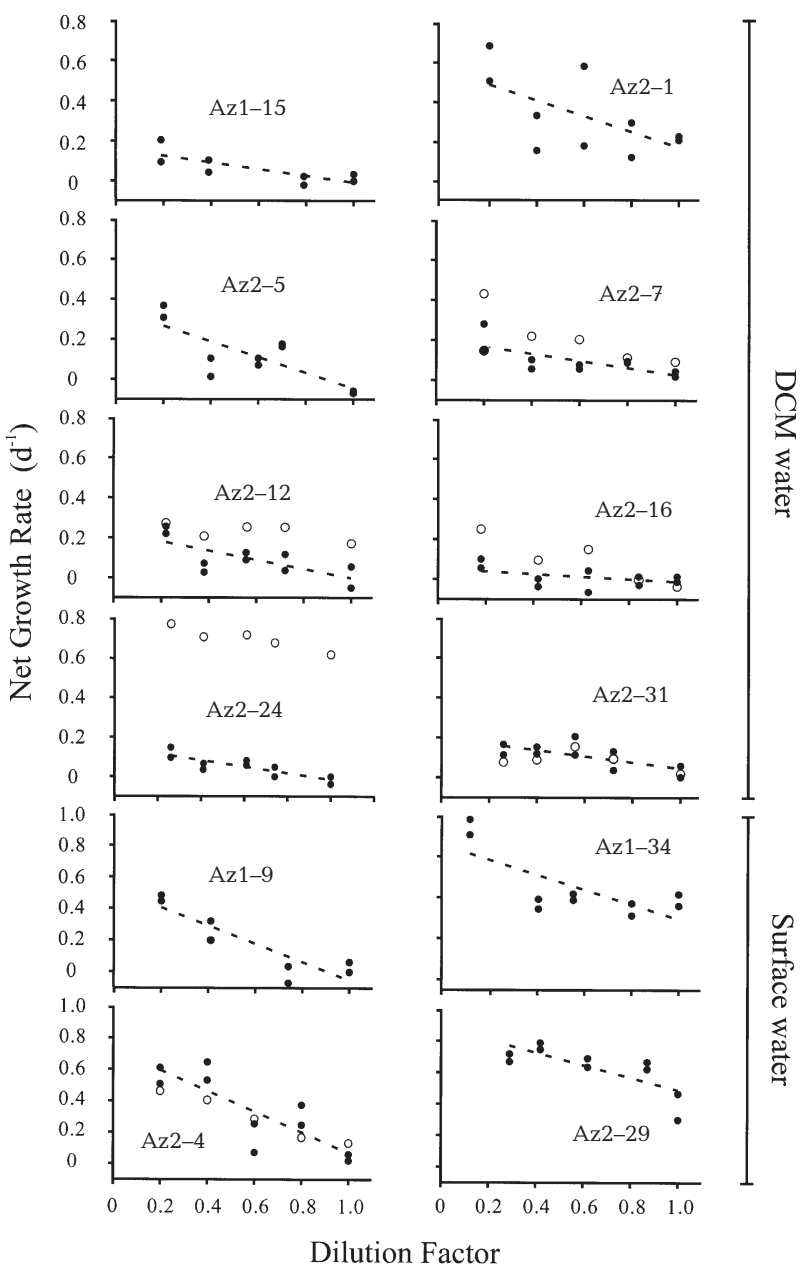

Fig. 2. Phytoplankton growth rate $(\bullet)$ in dilution experiments based on chl a measurements. Dilution factor $=$ the ratio between chl a concentration recorded in the dilution series and chl a concentration in natural seawater. (o) Total fluorescent particles in flow-cytometry analyses. Vertical scale for Az1-34 differs from those for the other stations (i.e. $=0$ to $1.6 \mathrm{~d}^{-1)}$. DCM, deep chlorophyll maximum 
Table 2. Summary of parameters and grazing impact by microzooplankton from dilution experiments. $\mu_{\mathrm{n}}$ : phytoplankton growth rate. $\mu_{0}$ : phytoplankton growth rate without added nutrients; $m$ : mortality due to grazing; PP: phytoplankton biomass production; $G$ : phytoplankton grazing losses; $\% P_{0}$ : standing stock grazed; $\% \mathrm{PP}$ : biomass production grazed; SE: standard error of regression parameters. ${ }^{* *}$ r significant at $\mathrm{p} \leq 0.01 ;{ }^{*} \mathrm{r}$ significant at $\mathrm{p} \leq 0.05$

\begin{tabular}{|c|c|c|c|c|c|c|c|c|c|}
\hline Stn & $\begin{array}{c}\mu_{\mathrm{n}} \\
\left( \pm \mathrm{SE} ; \mathrm{d}^{-1}\right)\end{array}$ & $\begin{array}{c}\mu_{0} \\
\left(\mathrm{~d}^{-1}\right)\end{array}$ & $\mu_{0}: \mu_{\mathrm{n}}$ & $\frac{m}{\left( \pm \mathrm{SE}_{;} \mathrm{d}^{-1}\right)}$ & $\mathrm{r}$ & $\begin{array}{l}\text { PP } \\
\text { (mg cl }\end{array}$ & $\begin{array}{c}G \\
\left.-3 \mathrm{~d}^{-1}\right)\end{array}$ & $\% P_{0}$ & $\% \mathrm{PP}$ \\
\hline Az1-9 & $0.52 \pm 0.08$ & 0.57 & 1.10 & $0.57 \pm 0.11$ & $0.89^{* *}$ & 0.030 & 0.031 & 57 & 102 \\
\hline Az1-34 & $1.30 \pm 0.15$ & 1.07 & 0.82 & $0.72 \pm 0.23$ & $0.73^{*}$ & 0.103 & 0.063 & 92 & 61 \\
\hline Az2-4 & $0.72 \pm 0.13$ & 0.71 & 0.98 & $0.65 \pm 0.18$ & $0.79^{* *}$ & 0.036 & 0.033 & 67 & 92 \\
\hline Az2-29 & $0.88 \pm 0.08$ & 0.70 & 0.79 & $0.39 \pm 0.12$ & $0.76^{* *}$ & 0.023 & 0.013 & 46 & 57 \\
\hline Az1-15 & $0.16 \pm 0.03$ & 0.20 & 1.25 & $0.17 \pm 0.05$ & $0.79^{*}$ & 0.061 & 0.044 & 17 & 73 \\
\hline Az2-1 & $0.57 \pm 0.12$ & 0.62 & 1.10 & $0.39 \pm 0.18$ & 0.60 & 0.115 & 0.073 & 44 & 63 \\
\hline Az2-5 & $0.34 \pm 0.07$ & 0.34 & 0.99 & $0.39 \pm 0.10$ & $0.78^{* *}$ & 0.162 & 0.155 & 39 & 96 \\
\hline Az2-7 & $0.20 \pm 0.04$ & 0.15 & 0.72 & $0.18 \pm 0.04$ & $0.71^{*}$ & 0.049 & 0.058 & 17 & 117 \\
\hline Az2-12 & $0.23 \pm 0.04$ & 0.14 & 0.60 & $0.24 \pm 0.07$ & $0.76^{* *}$ & 0.019 & 0.032 & 23 & 173 \\
\hline Az2-16 & $0.05 \pm 0.02$ & 0.07 & 1.30 & $0.06 \pm 0.04$ & 0.43 & 0.005 & 0.005 & 7 & 98 \\
\hline Az2-24 & $0.15 \pm 0.02$ & 0.12 & 0.83 & $0.16 \pm 0.04$ & $0.82^{* *}$ & 0.036 & 0.048 & 16 & 132 \\
\hline Az2-31 & $0.21 \pm 0.03$ & 0.16 & 0.74 & $0.19 \pm 0.05$ & $0.75^{* *}$ & 0.062 & 0.074 & 19 & 119 \\
\hline
\end{tabular}

Pacific (Landry et al. 1995) gave similar results, i.e. no significant deviation from the standard dilution technique. Thus we consider that effects through a nonlinear feeding response of grazers can be dismissed for our study. Examination of the available $t_{24}$ samples from 5 experiments showed no evidence of changes in overall microzooplankton abundance beyond the intrinsic variation of the counting method, of 10 to $20 \%$ (Gifford 1988). However, we found that larger oligotrich ciliates tended to be absent from $t_{24}$ samples. Although the counts of these cells always remained low in $t_{0}$ samples, the reduction in their numbers was evident in all $t_{24}$ samples. Therefore, mortality was affecting large Strombidium, Strobilidium and Tontonia species, probably due to handling problems related to their fragile nature and water pre-screening. We found no consistent change in the abundance of large

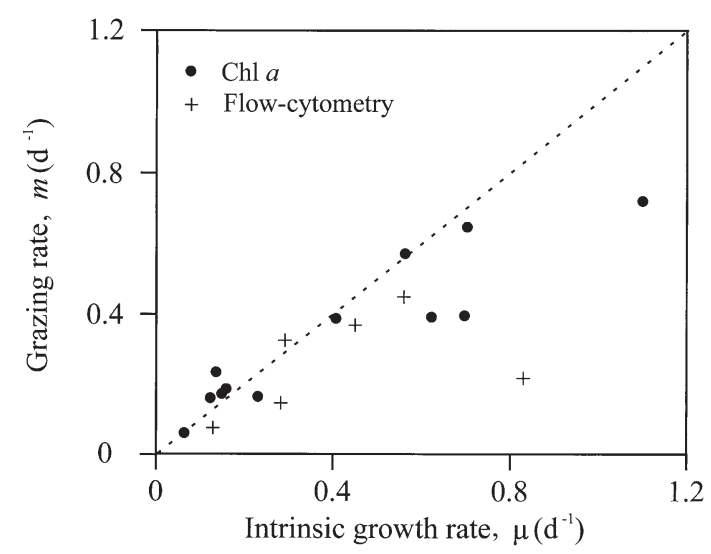

Fig. 3. Relationship between phytoplankton growth rate $(\mu)$ and rate of mortality due to grazing $(m)$ from dilution experiments. Dashed line represents 1:1 relationship gymnodinoid dinoflagellates, small ciliates or small dinoflagellates (small always refers to cells under $20 \mu \mathrm{m})$. Also, we chose the $20 \%$ dilution level as the most diluted treatment instead of the more common $10 \%$ or even $5 \%$ levels because of the especially oligotrophic nature of the system examined. Despite this, the effect of dilution on grazers, particularly ciliates, could somewhat affect grazing estimates, as recently reported by Dolan et al. (2000).

A total of 8 successful experiments were conducted with DCM water and 4 with surface water (Fig. 2). The average growth rate without nutrient addition, $\mu_{0}$, was statistically indistinguishable from that with nutrients, $\mu_{\mathrm{n}}$ (2-tailed paired-sample $t$-test, $t_{11,0.05}=1.58, \mathrm{p}=0.14$. $\mu_{0}: \mu_{\mathrm{n}}=0.93 \pm 0.22$, mean $\left.\pm \mathrm{SD}\right)$; thus phytoplankton growth did not appear to be nutrient-limited in the experiments. Phytoplankton growth, $\mu$, and mortality rates, $m$, were higher at the surface than at the DCM (Table 2) and showed a tight relationship (Fig. 3). PP ranged from 0.02 to $0.10 \mathrm{mg}$ chl a m $\mathrm{m}^{-3} \mathrm{~d}^{-1}$ in experiments with surface water and from 0.005 to $0.16 \mathrm{mg}$ chl a m ${ }^{-3} \mathrm{~d}^{-1}$ with DCM water. $G$ varied between 0.01 and $0.06 \mathrm{mg} \mathrm{chl} \mathrm{a} \mathrm{m}^{-3} \mathrm{~d}^{-1}$ at the surface and between 0.005 and $0.16 \mathrm{mg} \mathrm{chl} \mathrm{a} \mathrm{m}^{-3} \mathrm{~d}^{-1}$ at the DCM. Grazing impact on primary production ranged between 57 and $102 \%$ in surface water and between 63 and $173 \%$ in DCM water (Table 2).

Average $\mu_{0}$ and $m$ were quite different for the surface and the DCM (Table 3), and so was the the average microzooplankton grazing impact: $65 \%$ of $P_{0}$ and $78 \%$ of PP in the near-surface layer, and $23 \%$ of $P_{0}$ and $109 \%$ of PP at the DCM. PP was similar for surface and DCM water; thus, because $P_{0}$ was lower at the surface, turnover rates were higher in this layer. The net primary production of phytoplankton was very low, aver- 
aging $0.01 \mathrm{mg} \mathrm{chl} \mathrm{a} \mathrm{m} \mathrm{m}^{-3} \mathrm{~d}^{-1}$ for surface and ca zero for the DCM.

\section{Flow-cytometry analysis}

Of the 7 dilution experiments in which FCM analyses were conducted, 6 rendered the response expected from the dilution method (Fig. 4). All of these were from the DCM except for Az2-4, which was conducted with surface water. Results with FCM analyses were similar to those with bulk chl a (Fig. 2) with the exception of Az2-24, in which $\mu$ was very high and different from the chl a-based $\mu_{0}$ (0.83 vs $\left.0.12 \mathrm{~d}^{-1}\right)$. In contrast, mortality rates were more similar $\left(0.22\right.$ vs $\left.0.16 \mathrm{~d}^{-1}\right)$. The ratio between final and initial mean cell red fluorescence in this experiment was 0.95; therefore the result is difficult to explain based on photoadaptation. Possibly the FCM result for $\mu$ in this experiment was an artefact derived from an incorrect $t_{0}$ value of abundance; we therefore excluded Az2-24 from average calculations.

Average growth and mortality rates for the different phytoplankton groups are shown in Table 4. Mortality rates of the different groups within each experiment were not statistically different except for experiment Az2-16 (ANCOVA, $\left.F_{2,9}=8.22, \mathrm{p}<0.01\right)$, for which mortality was more intense for Synechococcus. For the rest of the experiments, we used the common slope $m_{c}$ to obtain average parameters. The FCM approach to dilution experiments yielded an average phytoplankton growth rate, $\mu$, and mortality rate, $m$, of 0.34 and $0.27 \mathrm{~d}^{-1}$, respectively. This indicates that $79 \%$ of the daily production of the phytoplankton community was being removed by protists.
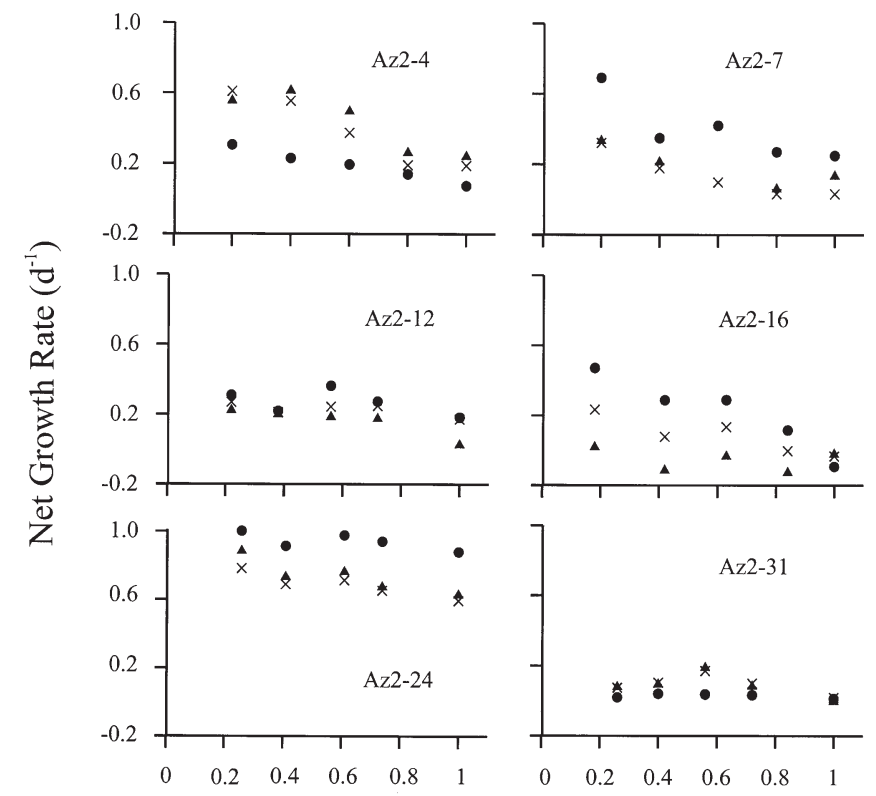

Dilution Factor

Fig. 4. Plots of dilution experiments using flow-cytometry analyses: (•) Synechococcus; $(\times)$ Prochlorococcus; (₫) nanoeukaryotes

Table 4. Average $( \pm \mathrm{SE})$ growth and grazing parameters resulting from flow-cytometry analysis. $\mu$ : growth rate; $m$ : mortality rate; PP: phytoplankton biomass production; $G$ : phytoplankton grazing losses; TR: turnover rate; $\% P_{0}$ : standing stock grazed; \%PP: biomass production grazed; SYN, PRO, Neuk, Total: Synechococcus, Prochlorococcus, nanoeukaryotes and total fluorescent cells, respectively

\begin{tabular}{|c|c|c|c|c|c|c|c|}
\hline & $\begin{array}{c}\mu \\
\left(d^{-1}\right)\end{array}$ & $\underset{\left(\mathrm{d}^{-1}\right)}{m}$ & $\begin{array}{c}\text { TR } \\
\left(\mathrm{d}^{-1}\right)\end{array}$ & $\begin{array}{c}\text { PP } \\
\left(10^{3} \text { cells } \mathrm{ml}^{-1} \mathrm{~d}^{-1}\right)\end{array}$ & $\begin{array}{c}G \\
\left(10^{3} \text { cells } \mathrm{ml}^{-1} \mathrm{~d}^{-1}\right)\end{array}$ & $\% P_{0}$ & $\% \mathrm{PP}$ \\
\hline PRO & $0.35 \pm 0.10$ & $0.26 \pm 0.07$ & 0.09 & 24 & 18 & 28 & 75 \\
\hline SYN & $0.40 \pm 0.11$ & $0.33 \pm 0.10$ & 0.08 & 6.6 & 5.4 & 34 & 82 \\
\hline Neuk & $0.32 \pm 0.12$ & $0.22 \pm 0.08$ & 0.11 & 1.6 & 1.1 & 22 & 68 \\
\hline Total & $0.34 \pm 0.07$ & $0.27 \pm 0.08$ & 0.08 & 30 & 24 & 28 & 79 \\
\hline
\end{tabular}




\section{DISCUSSION}

Herein we have reported measurements of phytoplankton growth and mortality due to grazing in the highly oligotrophic environment of the subtropical north-east Atlantic. We found a high degree of coupling between primary production and the consumption of protists, with a large fraction of phytoplankton production being channelled to herbivores.

In the Azores Current region, accumulation of phytoplankton biomass does not take place. Fernández \& Pingree (1996) offered a number of possible explanations, such as nutrient limitation and losses due to grazing. Since we measured an averaged chlorophyll grazing impact of protists on phytoplankton of 78 and $109 \%$ of PP removed daily for surface and DCM respectively, our data support the contention that the grazing activity of protists has a dramatic controlling effect on phytoplankton populations in oligotrophic, picoplankton-dominated systems. This is reinforced by the lack of evidence for nutrient limitation in our results, at least at the time scale of the experiments. Our results are highly compatible with an increase of microzooplankton grazing impact towards oligotrophic waters, as reported by Burkill et al. (1993) on a $60^{\circ} \mathrm{N}$ to $47^{\circ} \mathrm{N}$ transect in the NE Atlantic, which these authors attributed mainly to the size structure of the phytoplankton. In addition, our values of microzooplankton grazing impact are compatible with the grazing impact exerted by copepods during the same cruises, which averaged $27 \%$ of the primary production removed daily (Huskin et al. 2001).

The estimates of grazing impact achieved by the chl $a$ and FCM methods were not fully consistent, since the grazing impact on total FCM fluorescent cells was lower. However, the FCM experiments were fewer in number, and were based on 5-point regressions with the calculated $\mu$ corresponding to the nutrientenriched $\mu_{\mathrm{n}}$ in the bulk chl $a$ analyses. Caveats apart and after discarding photoadaptative effects, the differences could be due to scarce autotrophic flagellates with a high chl a content; these would appear in the bulk chl a analyses but remain undetected by FCM analysis. Because the FCM analyses in our study were more limited in scope than the chl a analyses, we ascribe more validity to the latter.

Phytoplankton growth rates were substantially higher in the surface mixed layer than in the DCM. In addition, the surface and DCM experiments showed different results in the sense that growth and grazing presented an imbalance in surface water, while average growth and grazing rates for the DCM were equal. This result therefore depicts a more dynamic environment in the upper mixed layer, with a higher potential growth of phytoplankton. In our understanding of the system, the DCM represents a structure close to steady-state, in which processes are slower than in the upper mixed layer or at higher latitudes in the NE Atlantic, which are characterised by marked seasonal changes in phytoplankton biomass and composition. This view of the DCM as a distinct, isolated system, agrees with the genetic differentiation between upper mixed layer and DCM populations of Prochlorococcus (Scanlan et al. 1996, West \& Scanlan 1999) and also with the existence of a persistent boundary between shallow and DCM phytoplankton species in oligotrophic, oceanic environments (Venrick 1988). The stability of wind stress in the area, which is under the direct influence of the subtropical high pressure belt in winter and the well known Azores High in summer (Tomczak \& Godfrey 1994), makes it conceivable that the differences between the upper mixed layer and the DCM could be fairly constant throughout the year. Although differences in growth parameters between the near-surface layer and the DCM were present, these did not obscure the tight relationship between $\mu$ and $m$ (Fig. 3). This relationship reflects the efficient coupling between phytoplankton and heterotrophs that would be expected from the turnover rate and standing stock of the oligotrophic system (Gasol et al. 1997).

Despite slight differences, the average growth and mortality rates of the different phytoplankton groups were essentially similar (Table 4 ). We obtained an average specific growth rate for Synechococcus $\left(0.40 \mathrm{~d}^{-1}\right)$ at the lower end of the wide range $\left(0.24\right.$ to $\left.1.4 \mathrm{~d}^{-1}\right)$ reported for the dilution technique (Christaki et al. 1999, and references therein). In the case of Prochlorococcus, the average specific growth rate $\left(0.35 \mathrm{~d}^{-1}\right)$ was in the upper range ( 0.09 to $0.48 \mathrm{~d}^{-1}$ ) reported by Goericke \& Welschmeyer (1993) for the Sargasso Sea. The magnitude of growth rates together with the dominance of Prochlorococcus in the community agree with the distribution and environmental requirements for picophytoplankton proposed by Veldhuis et al. (1993) for the eastern North Atlantic, whereby prochlorophytes tend to thrive in strongly stratified, nutrient-depleted waters. When the mortality rates are examined within each single experiment, only Sample Az2-16 showed significant differences between the FCM phytoplankton groups, with significantly higher grazing pressure on Synechococcus. Christaki et al. (1999) found in a laboratory experiment that 2 species of ciliates preferred to feed on Synechococcus rather than on Prochlorococcus, and proposed that the different distributions of the 2 autotrophic picoplankters were partly due to this fact. The results of our experiments did not clarify the subject, since the diverse assemblage of grazers would mask any group-specific preference in a near steady-state system. 
Microzooplankton abundance and biomass in the present experiments were lower than those of other open-ocean regions (Verity et al. 1993, Sleigh et al. 1996), as would be expected from the low phytoplankton standing stock. However, our grazer biomass data did not include the HNF, which were abundant during Cruise Az1, averaging $41 \pm 16$ cells ml$^{-1}$. Therefore, HNF should be taken into account as important contributors to the reported grazing impact of protists. The dinoflagellate-oligotrich ciliate balance could be interpreted as an indication of equilibrium in the microzooplankton community, since both compete for resources (Neuer \& Cowles 1995) and have different growth rates and feeding constraints (Hansen 1991, Pierce \& Turner 1992). This interpretation is consistent with the rest of our results, and with the small amount of variability in this system (Marañón et al. 2000).

The results of this study and our previous observations in similar areas suggest that the key factor for the success of dilution experiments in highly oligotrophic waters is strict control over manipulation and incubation procedures, i.e. absolute cleanliness, strict control of the incubation temperature, prevention of any pulse of intense irradiance that could cause irreversible physiological damage, and controlling for the influence of photoadaptation on the results. An equally strict control would be desirable in primary production or community respiration studies, especially when the subject is the delicate, largely stable phytoplankton populations of the oligotrophic ocean, which are adapted to narrow ranges of temperature and irradiance. In this connection, the photoacclimation response of Prochlorococcus, the dominant phytoplankter in the area, has been reported to notably exceed standard incubation times in diverse trophicrelated methods, even when exposed to narrow irradiance shifts (Bricaud et al. 1999). Thus, maintaining natural populations at the correct irradiance level during the whole process of on-deck incubations is central to accurately measuring the balance between productivity and grazing.

The data presented here show intense trophic coupling between primary producers and protist herbivores, and heavy consumption of particulate primary production. These results, in the context of a community characterised by temporal stability and low biomass, indicate little margin for a fate of the particulate primary production other than cycling within the phytoplankton-protist compartment. In addition, our study confirms the importance of including correct measures of the grazing activity of protists in the carbon budgets of the oligotrophic open ocean, and of rigorously controlling experimental procedures to avoid artefacts arising from a damaged community.
Acknowledgements. We are grateful to Fíz F. Pérez and Emilio Fernández for their support as leaders of the AZORES 1 and 2 cruises, to the staff of Spanish UGBO for their technical assistance, and to Leticia Viesca for her help onboard. We also thank Susanne Neuer for useful advise on the dilution method. Jaime Rodríguez and his team at Málaga University kindly provided access to their flow cytometer and help during sample processing. The comments of José Luis Acuña greatly focused and improved the first draft of the manuscript. Michael Landry and 2 anonymous reviewers made valuable suggestions that further improved the manuscript. This research was funded by the European Commission's Marine Science and Technology Programme (MAST III) under contract CANIGO (MAS3-CT96-0060) to R.A. The University of Oviedo funded a fellowship for M.Q. within the same project.

\section{LITERATURE CITED}

Behrenfeld MJ, Falkowski PG (1997) Photosynthetic rates derived from satellite-based chlorophyll concentration. Limnol Oceanogr 42:1-20

Bricaud A, Allali K, Morel R, Marie D, Veldhuis MJW, Partensky F, Vaulot D (1999) Divinyl chlorophyll a-specific absorption coefficients and absorption efficiency factors for Prochlorococcus marinus: kinetics of photoacclimation. Mar Ecol Prog Ser 188:21-32

Buck KR, Chavez FP, Campbell L (1996) Basin-wide distributions of living carbon components and the inverted trophic pyramid of the central gyre of the North Atlantic Ocean, summer 1993. Aquat Microb Ecol 10:283-298

Burkill PH, Edwards ES, John AWG, Sleigh MA (1993) Microzooplankton and their herbivorous activity in the northeastern Atlantic Ocean. Deep-Sea Res Part II Top Stud Oceanogr 40:479-493

Cebrián J, Duarte CM (1994) The dependence of herbivory on growth rate in natural plant communities. Funct Ecol 8: $518-525$

Christaki U, Jacquet S, Dolan J, Vaulot D, Rassoulzadegan F (1999) Growth and grazing on Prochlorococcus and Synechococcus by two marine ciliates. Limnol Oceanogr 44 : $52-61$

Cullen JJ (1982) The deep chlorophyll maximum: comparing vertical profiles of chlorophyll a. Can J Fish Aquat Sci 39: 791-803

Dolan JR, Gallegos CL, Moigis A (2000) Dilution effects on microzooplankton in dilution grazing experiments. Mar Ecol Prog Ser 200:127-139

Duarte CM, Cebrián J (1996) The fate of marine autotrophic production. Limnol Oceanogr 41:1758-1766

Fasham MJR, Platt T, Irwin B, Jones K (1985) Factors affecting the spatial pattern of the deep chlorophyll maximum in the region of the Azores Front. Prog Oceanogr 14: 129-165

Fasham MJR, Boyd PW, Savidge G (1999) Modeling the relative contributions of autotrophs and heterotrophs to carbon flow at a Lagrangian JGOFS station in the Northeast Atlantic: the importance of DOC. Limnol Oceanogr 44: 80-94

Fernández E, Pingree RD (1996) Coupling between physical and biological fields in the North Atlantic subtropical front southeast of the Azores. Deep-Sea Res Part I Oceanogr Res Pap 43:1369-1393

Fogg GE (1995) Some comments on picoplankton and its importance in the pelagic ecosystem. Aquat Microb Ecol 9:33-39 
Gaines G, Elbrächter M (1987) Heterotrophic nutrition. In: Taylor FJR (ed) The biology of dinoflagellates. Blackwell Science, Oxford, p 224-269

Gallegos CL (1989) Microzooplankton grazing on phytoplankton in the Rhode River, Maryland: nonlinear feeding kinetics. Mar Ecol Prog Ser 57:23-33

Gasol JM, del Giorgio PA, Duarte CM (1997) Biomass distribution in marine planktonic communities. Limnol Oceanogr 42:1353-1363

Gifford DJ (1988) Impact of grazing by microzooplankton in the Northwest Arm of Halifax Harbour, Nova Scotia. Mar Ecol Prog Ser 47:249-258

Goericke R, Welschmeyer NA (1993) The marine prochlorophyte Prochlorococcus contributes significantly to phytoplankton biomass and primary production in the Sargasso Sea. Deep-Sea Res Part I Oceanogr Res Pap 40: 2283-2294

González N, Anadón R, Mouriño B, Fernández E, Sinha B, Escánez J, De Armas D (2001) The metabolic balance of the planktonic community in the North Atlantic subtropical gyre: the role of mesoscale instabilities. Limnol Oceanogr 46(4):946-952

Hansen B, Bjørnsen PK, Hansen PJ (1994) The size ratio between planktonic predators and their prey. Limnol Oceanogr 39:395-403

Hansen PJ (1991) Quantitative importance and trophic role of heterotrophic dinoflagellates in a coastal pelagial food web. Mar Ecol Prog Ser 73:253-261

Huskin I, Anadón R, Medina G, Head RN, Harris RP (2001) Mesozooplankton distribution and copepod grazing in the subtropical Atlantic near the Azores: influence of mesoscale structures. J Plankton Res 23:671-691

Landry MR (1994) Methods and controls for measuring the grazing impact of planktonic protists. Mar Microb Food Webs 8:37-57

Landry MR, Hassett RP (1982) Estimating the grazing impact of marine microzooplankton. Mar Biol 67:283-288

Landry MR, Kirshtein J, Constantinou J (1995) A refined dilution technique for measuring the community grazing impact of microzooplankton, with experimental tests in the central equatorial Pacific. Mar Ecol Prog Ser 120: 53-63

Landry MR, Constantinou J, Latasa M, Brown SL, Bidigare RR, Ondrusek ME (2000) Biological response to iron fertilization in the eastern equatorial Pacific (IronEx II). III. Dynamics of phytoplankton growth and microzooplankton grazing. Mar Ecol Prog Ser 201:57-72

Lessard EJ (1991) The trophic role of heterotrophic dinoflagellates in diverse marine environments. Mar Microb Food Webs 5:49-58

Lessard EJ, Swift E (1986) Dinoflagellates from the North Atlantic classified as phototrophic or heterotrophic by epifluorescence microscopy. J Plankton Res 8:1209-1215

Editorial responsibility: Michael Landry (Contributing Editor), Honolulu, Hawaii, USA
Li W (1995) Composition of ultraphytoplankton in the central North Atlantic. Mar Ecol Prog Ser 122:1-8

Longhurst A (1998) Ecological geography of the sea. Academic Press, San Diego

Marañón E, Holligan PM, Varela M, Mouriño B, Bale AJ (2000) Basin-scale variability of phytoplankton biomass, production and growth in the Atlantic Ocean. Deep-Sea Res Part I Oceanogr Res Pap 47:825-857

Moigis AG (1999) Photosynthetic rates in the surface waters of the Red Sea: the radiocarbon versus the non-isotopic dilution method. J Plankton Res 22:713-727

Neuer S, Cowles TJ (1995) Comparative size-specific grazing rates in field populations of ciliates and dinoflagellates. Mar Ecol Prog Ser 125:259-267

Pierce RW, Turner JT (1992) Ecology of planktonic ciliates in marine food webs. Rev Aquat Sci 6:139-181

Pingree RD, García-Soto C, Sinha B (1999) Position and structure of the subtropical/azores front region from combined Lagrangian and remote sensing (IR/altimeter/SeaWiFS) measurements. J Mar Biol Assoc UK 79:769-792

Putt M, Stoecker DK (1989) An experimentally determined carbon:volume ratio for marine 'oligotrichous' ciliates from estuarine and coastal waters. Limnol Oceanogr 34: 1097-1103

Scanlan DJ, Hess WR, Partensky F, Newman J, Vaulot D (1996) High degree of genetic variation in Prochlorococcus (Prochlorophyta) revealed by RFLP analysis. Eur J Phycol 31:1-9

Sleigh MA, Edwards ES, John AWG, Burkill PH (1996) Microzooplankton community structure in the North-Eastern Atlantic: trends with latitude, depth and date, between May and early August. J Mar Biol Assoc UK 76:287-296

Tomczak M, Godfrey JS (1994) Regional oceanography: an introduction. Pergamon Press Ltd, London

Veldhuis MJW, Kraay GW, Gieskes WWC (1993) Growth and fluorescence characteristics of ultraplankton on a northsouth transect in the eastern North Atlantic. Deep-Sea Res Part II Top Stud Oceanogr 40:609-626

Venrick EL (1988) The vertical distributions of chlorophyll and phytoplankton species in the North Pacific central environment. J Plankton Res 10:987-998

Verity PG, Stoecker DK, Sieracki ME, Nelson JR (1993) Grazing, growth and mortality of microzooplankton during the 1989 North Atlantic spring bloom at $47^{\circ} \mathrm{N}, 18^{\circ} \mathrm{W}$. DeepSea Res Part I Oceanogr Res Pap 40:1793-1814

West NJ, Scanlan DJ (1999) Niche-partitioning of Prochlorococcus populations in a stratified water column in the Eastern North Atlantic Ocean. Appl Environ Microbiol 65: 2585-2591

Williams PJB (1998) The balance of plankton respiration and photosynthesis in the open oceans. Nature 394:55-57

Zar JH (1999) Biostatistical analysis. 4th edn, Prentice-Hall, Upper Saddle River, NJ

Submitted: November 10, 2000; Accepted: February 20, 2001 Proofs received from author(s): September 21, 2001 